the most important of which is the collection of Franklin manuscripts. Much work has been carried out in preparation for the issue of a descriptive catalogue of these manuscript collections.

\section{Smithsonian Publications}

A CLASSIFIED list of Smithsonian Publications, available for distribution, August 10, 1937, compiled by Helen Monro, has been published by the Smithsonian Institution, Washington (Publication 3394). The papers are supplied only as an aid to researches or studies in which the applicant is specially interested, and accordingly applicants are required to state the grounds for their request. Except where prices are given in the list, the papers are distributed gratis. The serial publications of the Smithsonian Institution are of three types: Smithsonian Contributions to Knowledge; Sm ithsonian Collections ; Smithsonian Annual Reports. The reports are distributed gratuitously to libraries and individuals throughout the world, but very few are now available at the Institution. The papers issued in the Contributions to Knowledge and Miscellaneous Collections are not public documents but are printed in limited editions and distributed without charge to public libraries, educational institutions and learned societies. They are supplied to other institutions and to individuals at the prices indicated.

\section{Calendar of Chemistry}

AN interesting list of names and dates has been drawn up by E. H. Huntress with the title: "Daily Chemical Anniversaries as a Teaching Tool", published in the Journal of Chemical Education (14, 328 ; 1937 ; obtainable in reprint form at a small charge). In this, each day of the year is assigned to some names of investigators distinguished for their contributions to chemistry and related sciences, who were born on that day in a year specified. The date of death is also given when the person is no longer living. In this way a valuable historical document has been produced, and it is clear from the brief introduction by the author that he has taken a great deal of trouble in collecting his material from reliable sources and in converting the dates based on different calendars to the Gregorian basis. He suggests that the list can be made use of in teaching, and it certainly offers interesting possibilities in this direction.

\section{Game Research}

AparT from a few special investigations, such as that on grouse disease, little persistent attempt has been made to study the diseases of game or methods of controlling disease or increasing the health and productivity of game. The opening a few years ago of a game research estate at Knebworth by Imperial Chemical Industries Ltd. was therefore a movement of scientific as well as of sporting interest, and now a second centre has been set up at Jealott's Hill, Warfield, Berkshire, for the study of problems relating to intensive rearing and the incidence of disease. From these stations appear occasional short pamphlets dealing with the progress of research or summarizing present knowledge regarding specific diseases. Advisory Leaflet No. 12 (June 1937) deals with a few diseases of game most commonly encountered on rearing-fields and amongst wild stock, and offers some suggestions for simple treatment such as a keeper could apply. The diseases referred to are gapes, coccidiosis, cramp, pneumonia, "sore mouth', and strongylosis or 'partridge disease'.

\section{Partridge Mortality}

THE question of "Partridge Stocks and Mortalities" is discussed in I.C.I. Game Researches, Advisory Leaflet 13, June 1937. The pamphlet is based upon information gathered from a large number of partridge manors throughout Great Britain and analysed by A. D. Middleton, of the Bureau of Animal Population. The matters discussed include losses of nests, fertility of eggs, mortality in young partridges, stock estimates, winter wastage, mortality and its reduction. The pamphlet is simply written and should be a useful guide to the shooting man and his keeper-to whom the original papers are not likely to be available-as to what may be expected amongst a normal stock of wild partridges.

\section{Bibliog raphy of Seismology}

THE recent quarterly part of the "Bibliography of Seismology", edited by Mr. Ernest A. Hodgson, concludes the record for the year 1936 (Pub. Dominion Observatory, Ottawa, 12, 1936-37). The value of the work will be evident from the fact that the number of entries for the year is 429 . To a great extent, the practice of adding notes on, or abstracts of, the memoirs is abandoned. On the other hand, the useful plan of giving references to notes or articles in various scientific journals-such as NATURE, Science, etc., and the Proceedings of such bodies as the Academy of Sciences of the U.S.S.R., the Geodetic Survey of India and the Society of Petroleum Geophysicists-is extended. The countries in which earthquakes are studied are now so well represented on the list of contributors that few, if any, memoirs of importance can escape notice. The last number contains a useful subject-index under more than fifty headings.

\section{An Active Sunspot}

A LARGE and active group of sunspots, visible to the naked eye, is in transit across the sun's disk (September 28-October 11) in latitude $10^{\circ} \mathrm{N}$. The date of central meridian passage was October $4 \cdot 6$. The following measures of area made at Greenwich and expressed in millionths of the sun's hemisphere illustrate the rapid growth of the group from September 28, when it was seen coming into view at the sun's east limb :

\begin{tabular}{|c|c|}
\hline Sept. $28 \cdot 4 \mathrm{~d}$ & Area 450 \\
\hline " $29 \cdot 3$ & $\begin{array}{ll}1100 \\
1700\end{array}$ \\
\hline oc̈t. $\begin{array}{r}30 \cdot 4 \\
1 \cdot 3\end{array}$ & $", 2100$ \\
\hline $4 \cdot 4$ & , 3100 \\
\hline
\end{tabular}

By October 1, a number of separate nuclei had developed into one very long complex spot. (Continued on p. 641) 